\title{
Harnessing Mineral Resources in Gwanda district of Zimbabwe: A Myth or a Reality?
}

\author{
Funa Moyo*, Clifford Mabhena \\ Institute of Development Studies, National University of Science and Technology, \\ Bulawayo, Zimbabwe \\ *E-mail address: funa.moyo@nust.ac.zw ,fmoyo2011@gmail.com
}

\begin{abstract}
The article examines strategies of harnessing mineral resources for community empowerment, poverty reduction and infrastructure development in mining areas of Zimbabwe. Despite abundant mineral resources, the majority of Zimbabwean indigenous communities living close to the mines have limited access to directly or indirectly benefit from the mineral resources. Using a descriptive survey to collect data, this research article gives a strong proposition on how the Indigenisation and Economic Empowerment Act can be used as a vehicle of harnessing mineral resources. The article argues that pro poor mining policies that ensure the harnessing of mineral resources for community empowerment, poverty reduction and infrastructure development are paramount. The article further argues that the Indigenous and Economic Empowerment Act needs to be harmonised with other sector legislation in the country. The article concludes that the development of infrastructure and provision of public utilities such as electricity, water, establishing micro-credit to small and medium enterprises and implementing broad-based indigenisation policies are some of the strategies of improving rural livelihoods. Similarly direct and indirect linkages between the mining sector and local economy could be enhanced through the provision of food supply to the mine, manufacture of mining inputs, provision of security services and supply of labour by the local community. The article recommends that the harmonisation of legislation that has an effect on harnessing of mineral resources by local communities will ensure community empowerment, poverty reduction and infrastructure development.
\end{abstract}

Keywords: Harnessing; mineral resources; empowerment; indigenisation; community

\section{INTRODUCTION}

The development of mining settlements was more rapid in the American West, where independent miners rather than companies were involved, (Bryceson and MacKinnon, 2012). Most famously, the California gold rush of 1848-53 spurred a massive migration of some 300000 people from the Eastern United States of America, Europe, Latin America and Asia, (Holliday, 2002). The so called '49ers' lived in mining camps that sprung up around goldfields, which were notorious for their poor conditions, (Brands, 2002). More recently, the American West experienced a resource boom in the late 1970s and the early 1980s. The effects of the rapid economic and demographic changes taking place in mining towns at that time prompted the diagnosis of 'Gillette Syndrome', (Bryceson and MacKinnon, 2012). 
In Australia the adoption of the so called 'fly in, fly out' systems whereby labour is flown in on a weekly basis to remote regions such as Pilbera in Western Australia (Lawrie, Tonts, Plummer 2011, Storey 2001) fosters a process of indirect urbanisation since some of the urban development's effects take place in workers' towns of residence in addition to the mining towns themselves in particular, this has reinforced the growth of Perth as the primary regional service centre and to a lesser extent Melbourne, which has been the centre of corporate control in Australian mining since the $19^{\text {th }}$ century Victorian gold rush, (Tonts and Talyor 2010:2656).

In Latin America silver mining was foundational to the economic and spatial organisation of the Spanish Empire. Mines catalysed the growth of the largest urban centres in the Americas, (Dore, 2000). The city of Potosi in today Bolivia was founded on silver mining attaining a population of 200000 at the turn of the $17^{\text {th }}$ century. Latin American governments sponsored major resource based growth pole projects to develop remote regions spurring the transformation of the Amazon region. Along large-scale state led mining projects, Amazonia experienced an influx of artisanal prospectors or garimperios as part of the massive gold rush after a rise in the gold price in 1979, (Godfrey, 1992).

Bryceson and MacKinnon, (2012) note that after the scramble for Africa, economic and political influences took a new direction. They argue that the colonial governments structured their urban policies towards: first, limiting urban growth with the intention of keeping Africans in their rural home areas; second, facilitating labour control of African migration to the city, (Rakodi, 1986); and third, segregating the races spacially within the city, using byelaws and the 'cordon Sanitaire' under the pretext of ensuring European public health, (Swanson, 1977). Urban areas were in effect, conceptualised as an alien environment that would contaminate individual Africans and corrode the communal fabric of tribal Africa.

Bryceson and MacKinnon, (2012), contend that the upsurge of mining currently restructuring many national economies in Africa is raising important questions about priorities in natural resource utilisation and distribution of present and future mining wealth in countries concerned. They argue that the demographic and economic changes related to mining over the $20^{\text {th }}$ century have largely been ignored; instead large scale mining complexes dominated literature with their racially segregated housing and attempts to constrict African urbanisation through a bachelor wage and oscillating migration between miners' rural homes and mine sites. Bryceson and MacKinnon further argue that in many parts of sub Saharan Africa, mining has become a source of conflict, reflecting the often irreconcilable claims of different groups for control over wealth. They argue that conflicts have multiplied in recent years as mining operations have expanded, often pitting mining corporations or the state against communities, (See also Richards, 1996, De Boeck, 1998, Bryceson and Mwaipopo, 2010, Mabhena, 2012).

\section{THE AFRICAN MINERAL RENAISSANCE}

There is an emergent realization that mining could be a key instrument in establishing infrastructure $^{1}$ for development of other sectors, such as agriculture and forestry. This is embodied in the NEPAD Sustainable Development Programme (SDP) initiative and also in the Africa's Mining Vision (AMV), United Nations Economic Commission for Africa(UNEC) (2011).

\footnotetext{
${ }^{1}$ Transport, energy and water
} 
In 2009 the African Union (AU) Heads of State adopted "African Mining Vision" that contains important strategies for the maximization of the impact of mineral resources on growth and development. Many African countries do not have sustainable development principles in their national mining policies ${ }^{2}$. Hence the African Mining Vision aims to achieve a "knowledge -driven African Mining sector that catalyses and contributes to the broad-based growth and development ${ }^{3}$. The vision envisages establishing a mutually beneficial partnership between the state, the private sector, civil society, local communities and other stakeholders. Thus mineral resources must benefit all the citizens of a country and not just a few elite and multi-lateral companies.

Harnessing mineral resources for economic development and community empowerment is critical in improving the quality of life for all citizens in Zimbabwe. Corporate Social Responsibility (CSR), Mining Royalties (MR) and of late Community Share Ownership Trusts (CSTOs) in Zimbabwe have been used as vehicles of harnessing mineral resources for community empowerment, poverty reduction and infrastructure development. The article argues that CSR, MR and CSTOs can be used as tools to harness mineral resources for sustainable development and poverty reduction in Zimbabwe and Matabeleland in particular.

\section{HISTORICAL PERSPECTIVE OF THE HARNESSING OF MINERAL RESOURCES IN ZIMBABWE (1965-2010)}

The 11 November 1965 Unilateral Declaration of Independence by Ian Smith regime established Rhodesia, a country characterized by an extremely racial type of society where the indigenous population was disposed of rights to their natural resources. Natural resources such as prime land, minerals, indigenous forests and water were the preserve of the white people. Acquisition of mining rights was an exclusive preserve of the white Rhodesians. The African people in the then Rhodesia were not allowed to own mines.

The black population tried to resist this unfair situation through the Anglo-Ndebele war of 1893, Ndebele Up rising 1896-97(Impi yomvukela) and the chimurenga 1 (1897) war. The defeat of the early liberators further reinforced the discrimination in the ownership and utilisation of mineral resources. The documentation of acquisition of mining rights dates as far back as 1895, when the Mines and Minerals Ordinance was used to register title to mining locations.

The rights conferred were for both the land and mineral resources, (Maturure, 2008). Beneficiaries of this set up were the white settlers and their descendants. The 1960-1980 liberation struggle was fought to redress these imbalances. However, even after independence the acquisition of mining rights is restricted to the elite, companies and partnerships of not more than six persons. Communal people operate in varying group dimensions and hence have been left out of the formal mining sector, leading to the rise of artisanal mining, (Moyo and Mabhena, 2012).

Zimbabwe is estimated to have more than 1000 registered mines producing about 35 minerals, (Kanyenze, Kondo, Chitambara and Martens, 2011). Mineral resources, such as gold, emeralds and diamonds, have provided a means of livelihoods to the unemployed

\footnotetext{
${ }^{2}$ United Nations Economic Commission for Africa (UNECA), 2009

${ }^{3}$ The ANC Policy Discussion Document, 2012
} 
people in both rural and urban areas of Zimbabwe from 1991 to 2009, through artisanal mining an activity deemed illegal by Zimbabwe state apparatus, (Mabhena, 2012).

There is a general belief in Zimbabwe that poverty and lack of community social and economic empowerment has been caused by mining companies. Lack of sustainable development in the communities close to mines and the country in general has also been caused by the behaviour and operations of the mining companies. The mining sector continues to be one of the biggest contributors to the economy through the payment of mineral royalties, employee income taxes, corporate taxes and ancillary levies. Despite the revenue that Zimbabwe derives from mining activities, there is growing unease with regard to the real benefits accruing to the ordinary Zimbabwean in the mining communities. In a study in Ghana, Mining companies have also been accused of shirking their responsibility towards the development of the communities in which they operate, thereby increasing the level of poverty and vulnerability in these communities, (Ababio and Boon, 2009).

This article examines the strategy of harnessing mineral resources for community empowerment, poverty reduction and infrastructure development in Gwanda rural district of Matabeleland South. The communities where resources are extracted have been looking on and watching their resources being taken out of their communities while they remained engulfed in poverty. Hence, the Indigenisation Statutory Instrument ${ }^{4}$ is any attempt to expedite harnessing of mineral resources for social and economic empowerment and to allow communities where minerals resources are, to benefit from the extraction of the mineral in their area. Thus the Indigenisation and Economic Empowerment Act stipulates that people can benefit through Community Share Ownership Schemes and Employee Share Ownership Schemes/Trust, (Mabhena and Moyo, 2014). The article assesses how the mineral resources have been effectively harnessed to socially and economically empower local communities in Gwanda rural district. However some political analysts and development practitioners argue that the harnessing of mineral resources must help to reduce poverty, trigger infrastructural development and enhance community empowerment and community transformation. Corrupt mining tendencies which focus on benefiting the elite at the expense of the majority must be avoided at all cost.

For more than two decades, Zimbabwe has been implementing strategies that support human livelihoods through the use of natural resources. This has been done within the context of Community Based Natural Resources Management initiatives (CBNRM). Harnessing of the country's wealth requires dynamic political-economic institutions which are responsive to needs of the citizens of a country. However a key challenge for Zimbabwe is the development of policy frameworks to ensure capture of mineral wealth and the creation of long-lasting benefits to local communities. In view of the above situation, the Government of Zimbabwe took bold legislative frameworks to address the anomaly in the distribution of the country's wealth. In 2004, the government of Zimbabwe gave notice of its intention to increase local ownership of mines. The Government of Zimbabwe had drafted a Global Indigenization Bill, which was subsequently debated and passed into law on $18^{\text {th }}$ of April 2008, (Martins, 2008).

Mining has the potential of contributing significantly to poverty reduction and social and economic empowerment. Weber-Fahr et al (2001: 30) asserts that "large-scale mining can contribute, through higher incomes, to better nutrition and better education and thus improved health profiles in a community". Indigenous populations that live in mining areas believe that they should also share the wealth created by mining. The article argues that the

\footnotetext{
${ }^{4}$ Statutory Instrument 21 of 2010
} 
proceeds from mineral wealth can be channelled to the local communities through cash transfers, equity shares royalties and community share ownership trusts. Mineral resources can be harnessed to socially and economically empower the local communities through the following forms:

1. Investment in education and health, often provided initially for the mine employees, but then extended to the general public.

2. Investment in local government capacity (planning for and management of services of mutual interest)

3. Investment in other community - related services or activities with universal access, best in conjunction with the local authority, (Weber- Fahr, 2001).

The mining sector can be used by governments as an engine for overall economic growth and as a source of financing to support social sector and poverty reduction. Revenues can be directed to local communities through cash transfers, equity shares and other mechanism, (Weber-Fahr, Strongman, Kunanayagam, and Sheldon, 2001).

Mineral resources can be harnessed to contribute to the socio-economic well-being of the communities in the area of its operation. Improvements may include areas such as infrastructure, health, education and the stimulation of the local economy, (Mabhena and Moyo, 2014). Mineral wealth if managed right could be the transformational vehicle through which Zimbabwe can turn around its failing economic fortunes, while also serving as an example to other African countries blessed with mineral riches, (Martin and Taylor, 2012). Frucs and Agba (2007:13) assert that "revenue from mineral production could aid poverty alleviation and increase economic development in rural areas. The UNESC (2009) declares that with good and transparent governance, the exploitation of mineral resources can foster economic and social growth and reduce poverty. Pedro (2005) adds that mineral wealth should be invested to create a new wealth and used to create forms of renewable capital which are key to achieving sustainable development. Mining has a key contribution to make in achieving poverty and hunger reduction, gender equity, health, education and environmental and developmental enhancement objectives in line with the Millennium Development Goals, (Hodge, 2011).

\section{MINERAL WEALTH AND EMPOWERMENT}

Africa is characterised by high levels of poverty and underdevelopment in spite of the abundant mineral resources, The Zimbabwe Mining Indaba (2012). The range of natural resources refers to non-renewal resources such as oil, gas, mineral and metals, (Andres Mejia, 2011).

Martin and Taylor (2012) revealed that, mining has a huge potential to either contribute significantly to poverty reduction and social and economic empowerment. According to Bryn and Hofmann (2007) mineral wealth must be used for broad development purposes that improve the lives of citizens. Bryn and Hofmann (2007) further advanced that if well managed, revenues from the mineral wealth could help alleviate poverty and spur development in many countries that, despite their wealth are currently near the bottom of international human development indicator rankings. Andres Mejia (2011) concurred with Bryan and Hofmann (2007) when he concluded that mineral resources if well invested could alleviate socio-economic inequalities among citizens. 
Scholarly literature reveal that revenue from mining should spur economic growth and social development, reduce poverty and enhance social and economic empowerment in developing countries, (Bryn and Hofmann (2007), Andres Mejia (2011), Martin and Taylor (2012) and The Zimbabwe Mining Indaba (2012).

According to Bryan and Hofmann (2007) countries that have successfully used proceeds from the extractive industries for national development purposes, includes Australia, Canada and Norway which have developed high standards of accountability and transparency in mineral resource governance and trade. Ghana and Botswana are widely perceived as models of successful management of natural resources for social and economic development. The resource-rich countries like Botswana have financed collective goods mainly through mineral rents rather than aid, (O'Connell and Dolan, 2011). Bryan and Hofmann (2007:24) add that, "since the discovery of diamonds in 1967, diamond revenues have helped fund investments in infrastructure, education, health and other development programs". Hence mineral resources may be used as a basis for the industrialization, job creation, poverty eradication, capacity building and community empowerment and improvement of people's lives.

\section{ZIMBABWE'S ECONOMIC AND SOCIAL EMPOWERMENT STRATEGY}

The effective harnessing of mineral revenue for economic and social empowerment calls for the design of national fiscal policy frameworks focusing on socio-economic development and poverty alleviation, $\left(\mathrm{ECA}^{5}, 2011\right)$. However a key challenge for many countries is the development of policy frameworks to ensure capture of mineral wealth and the creation of long lasting benefit to local communities, (Fosu, 2011). Hence, Weber-Fair, Strongman, Kunanayagam, McMahan and Sheldon (2013) argue that, it is important that there is legislative framework to determine the split of revenue between the national government, local government and community (landholder). Mate (2002:3) posits that the political will to enforce the law must be present in order for a government to implement community empowerment initiatives. Mate (2002) adds that regularizing the activities of small-scale mining sector within a legal framework would create opportunities for growth and enhance social development. Zimbabwe has lagged behind in terms of the establishment of an enabling legal and policy framework for sustainable and equitable mineral resource development. The country has fast tracked economic empowerment through the indigenisation legislation, (Murombo, 2010).

The model of Zimbabwe's indigenisation and economic empowerment law places prominence on wealth creation through broad-based participation of indigenous people in economic activity, (Musarurwa , 2012). The $\mathrm{IEE}^{6}$ Act is suitably tailored to promote inter and intra-generation equity in the mining sector in Zimbabwe and to ensure that current mining activities do not prejudice the interests of future generations in mineral resources, (Murombo, 2010). Zimbabwe's economic and social empowerment strategy aims at ensuring equity and equitable distribution of the benefits especially with regard to legally and politically disempowered local communities such as the Chiadzwa communities in the Marange diamond fields of Zimbabwe, (Murombo, 2010).

\footnotetext{
${ }^{5}$ ECA-Economic Commission for Africa

${ }^{6}$ IEE-Indigenisation and Empowerment Act, 2004
} 


\section{MINERAL POLICIES}

Southern African governments should develop policies, strategies and interventions that maximise growth, development and employment, potential embedded in their mineral resources $^{7}$. In the most successful economies, the state's role as facilitator of investment is balanced by its role, for example, as regulator that establish laws and policies. In most cases, constitutions vest natural resources in the people but grant the government and the local authority to manage those resources on their behalf, (Bryan and Hofmann, 2007). However Frucs and Agba (2007) argue that provision of appropriate legal and policy frameworks, together with adequate level of political stability, will attract investors to the rich mineral deposits. The MPRD Act of 2002, Bryan and Hofmann (2007) and Frucs and Agba (2007) discuss the issues related to the study by addressing the importance of mining policies.

Bryan and Hofmann (2007:24) contend that "civic organisations in Ghana advocate for government policies to ensure that appropriate royalties are paid and jobs created and that benefits accrue to communities where natural resources are extracted". Frucs and Agba (2007:8) agree with Bryan and Hofmann (2007) when they advance that governments have to implement a policy framework to ensure mineral wealth is captured and creates a long lasting benefit for local community and population and maximise 'value-added' from mineral extraction. Fosu (2011:29) brings in another dimension to the issue of mining policies by declaring that "a key challenge for many countries is the development of policy frameworks to ensure capture of mineral wealth and the creation of long-lasting benefit to local communities. The effective harnessing of mineral revenue for economic and social empowerment calls for the design of national fiscal policy frameworks which focus on mining for growth, socio-economic development and poverty alleviation, (ECA, 2011). The ECA (2011) reveal that the Lagos Plan of Action for Economic Development of Africa 19802000 called for the establishment or strengthening of national machinery for the creation of policies to ensure that proper backward and forward linkages exist between these resource sectors and other sectors of the economy in order to promote rural development. Unfortunately, Global Witness et al cited in Mabikkhe (2012: 5) declare that most resourcerich countries of Africa are characterised by weak governance, outdated laws and weak institutional capacity. It further declared that outdated laws create a conflict of interest within those tasked with implementation.

\section{ZIMBABWE'S MINERAL POLICIES}

Post- independence era was expected to bring prosperity and access to opportunities in the 'closed' mining industry in Zimbabwe. The Mines and Mineral Act (chapter 21:05), which is oriented towards resource extraction, together with other legislation, continue to govern the resources extraction industry to the detriment not only of the environment, but more importantly, to the detriment of the communities living in mineral bearing areas, (Murombo, 2010:869). Without doubt, law does play a crucial role in regulating access to the mining industry and it is an indispensable variable in the equation of sustainable mining. Mate (2002:3) posits that the state determines the framework within which mineral exploitation occurs as well as the manner in which mineral wealth is used. According to Kanyenze, Kondo, Chitambara and Martens (2010:194) mining law in Zimbabwe allows for

\footnotetext{
${ }^{7}$ MPRD Act-Mineral and Petroleum Resources Development Act (2002:3).
} 
private-sector ownership of mining concerns. The ownership structure of business involved in mining range from those listed on the Zimbabwe Stock Exchange, government-owned and limited-liability companies, foreign-owned and indigenous companies, co-operatives and syndicate. Kanyenze et al (2010:194) argue that first time that the issue of broadening the ownership of mining was raised when the Zimbabwe Programme for Economic and Social Transformation (ZIMPREST) was announced in 1998, one of whose objectives was economic empowerment in mining. However, Murombo (2010:573) argue that the overarching statute governing the mining sector in Zimbabwe is the Mines and Minerals Act enacted in 1961 which is proposed to be amended and the IEE Act.

The question to be asked is whether Zimbabwe's mining laws, read with the IEE Act are suitably tailored to promote inter-generational equity in the mining sector in Zimbabwe?, (Murombo (2010). The response to the above question has been the reincarnation of the Mines and Minerals Amendment Bill of 2007 as the Indigenisation and Economic Empowerment Act of 2007 and the 2010 Regulations, (Murombo, 2010). He added that proposal for extensive rearrangements of mining rights, how they are acquired and the empowerment of indigenous Zimbabweans is phenomenal both in the positive and negative sense. Kanyenze et al (2010:206) support Murombo (2010 when he argued that Zimbabwe can benefit from policies that allow broad-based economic empowerment and the distribution of wealth to empower the indigenous people. However, Murombo (2010:579) asserts that without the necessary legal predicate, local communities in Zimbabwe will continue to suffer at the hands of mining companies. Additional, Mabikkhe (2012:5) asserts that the benefits from the mineral sector can be a curse to the entire nation if mineral wealth is concentrated in the hands of a few powerful officials. Hence Kanyenze et al (2010) and Murombo (2010) agree that the indigenisation agenda is in essence part of an empowerment process for the less privileged indigenous Zimbabweans. However Mabikkhe (2010) and Saunders (2007) warn that a network of elite-driven, opportunistic and greed politically connected individuals may hijack a noble empowerment programme for their selfish needs.

\section{CORPORATE SOCIAL RESPONSIBILITY}

Corporate Social Responsibility (CSR) is another policy initiative advocated by the African Mining Vision, which aim to contribute to wider development objectives. As CSR could be voluntary or legislated, it is important to entrench CSR in any policy framework in a manner that is clear about the responsibility of mining companies and government, (ECA (2011).There is no generally accepted definition of CSR and no consensus on the list of issues it covers. According to ECA (2011:87) most definition of corporate social responsibility describe it as constituting actions where by enterprises integrate societal concerns into their business policies and operations, including environmental, economic and social concerns.

The ECA (2011) added that it is necessary for mining companies to embrace the notion of CSR in order to contribute to wider development objectives. However the Mining Indaba (2012:2) noted with great concern that "CSR is not a legal obligation, yet it could contribute significantly to community development" Hence the government of Zimbabwe must ensure that corporate social accountability and responsibility shifts from being a voluntary to mandatory mechanism with agreed minimum standards which directly benefit the affected communities, (The Mining Indaba, 2012). Without frameworks compelling mining companies to do this, community concerns continue to be treated as peripheral and any 
contributions are just charity. These views have changed as business now accepts that CSR is necessary. The evolution of CSR according to the ECA (2011:103) has led to the mining industry accepting that implementing community development programmes and behaving as responsible corporate citizens are good business practice. The ECA (2011) adds that mining companies now accept that for communities living in areas in which they operate, to live without basic services such as water, health care, electricity and sanitation, is unacceptable for good business.

\section{CORPORATE SOCIAL RESPONSIBILITY FRAMEWORKS}

Today there is a proliferation of CSR frameworks, norms and reporting formation, some legislated, but most guidelines or voluntary codes. These diverse sources include the UN Conferences, intergovernmental bodies such as the International Labour Organisation (ILO), the Organisation for Economic Co-operation and Development (OECD) and the World Bank- national legislation, groups of international private financial institutions, industry associations and multi-stakeholder bodies, (ECA, 2011:101). Hence many companies understand that addressing CSR needs in communities will benefit them, so adopting CSR is enlightened corporate 'self-interest'. For instance in early 2010, Anglo American joined the Business Call to Action with its commitment to tackle poverty, empower underprivileged individuals and promote economic growth in South Africa's mining and labour - sending communities, (Anglo American Case Study, 2011).

The Anglo American Case Study (2011) expressed similar sentiments advanced by the African Mining Vision which reaffirmed Africa's commitment to prudent, transparent and efficient development and management of its mineral resources to meet the MDGs, eradicate poverty and achieve rapid and broad -based socio-economic development, (UNESC, 2009). However, from a policy perspective, CSR initiatives should not be considered a substitute for government responsibility towards its citizens in providing basic infrastructure and other public goods. CSR could reduce the motivation of government to fulfil its responsibilities to its citizens and the latter could come to see the mining companies as provider of those services that they should be looking to the state, (UNSEC, 2009). CSR initiatives should complement government efforts through local government institutions and local authorities, (ECA, 2011). The ECA (2011:109) contends that the framework that a government chooses to entrench CSR should be clear about the responsibilities of mining companies and which responsibilities should be matched with and communicated to communities living close to mining companies.

Some African countries have created statutory framework for CSR. The MPRD Act (2004) of South Africa, for example, requires an applicant for a mining right to submit social and labour plans. Regulation 41 objectives are:

a) Promote employment and advance the social and economic welfare of all South Africa.

b) Contribute to the transformation of the mining industry

c) Ensure that holders of mining rights contribute towards the socio-economic development of the areas in which they operate (Economic Commission of Africa, 2011). 
The legislative provisions of the MPRD Act 2004 of South Africa are similar to those of the Nigerian Minerals and Mining Act (2007) which also requires that the holder of a mining concession should ensure economic benefits to the community. ${ }^{8}$,

According to the ECA(2011:103) the agreement, to be reviewed every five years, must address "all or some----[matters] when relevant to the host community which are set out in section 116[3], as well as mechanisms for the community to participate in the planning, management and monitoring of activities carried out' under it (section 117)".

\section{EMPLOYEE SHARE OWNERSHIP SCHEMES}

There are various mechanisms to ensure impacts on local economic development, ranging from the establishment of local foundations to equity share arrangements, (WeberFahr, Strongman, Kunanayagam, Mc Mahan and Sheldon, 2001). Musarurwa (2012) contends that an employee share ownership scheme is a contribution plan that provides a company's workers with an ownership interest in the company.

He goes on and add that, under such schemes, companies provide their employees with stock ownership, typically at no cost to the employees. Matyzak (2012:11) asserts that "Zimbabwe Platinum Mines agreed to shed 10 percent to workers". Musarurwa (2012:3) supports Matyzak (2012) by declaring that "Pretoria Portland Cement (PPC), South Africa's biggest cement producer, has also agreed to extend a cumulative 5 per cent shareholding of the company to its workers".

The UNESC (2009:8) reveal that African ownership of mineral assets has increased because of Black Economic Empowerment (BEE) schemes. Local equity participation in mining projects has been promoted and embedded into law in South Africa, (UNESC, 2009).

Employee share ownership schemes are not peculiar to Zimbabwe's indigenisation and economic empowerment drive. However, within the local context they are a critical element in ensuring that Zimbabweans are economically empowered.

Although they are a critical component of the local indigenisation and economic empowerment drive, employee share ownership schemes are commonplace across the globe, Musarurwa (2012).

In the United States, for example, there are approximately 11300 employee share ownership plans for over 13 million employees, according to the country's National Centre for Employee Ownership. In terms of the indigenisation law, the setting up of employee share schemes is not mandatory, but discretionary, (Musarurwa, 2012).

According to Musarurwa (2012:2) the model of Zimbabwe's indigenisation law places prominence on wealth creation through broad-based participation of the indigenous people in economic activity.

In terms of the country's indigenisation and economic empowerment law, foreignowned firms are required to set aside a 5 percent (and up to 28 per cent) stake for ordinary workers. On the other hand, management share ownership schemes should not exceed 5 per cent. Big mining companies, such as Zimbabwe Platinum Holding, Mimosa and Anglo Platinum have already launched their employee share schemes.

\footnotetext{
${ }^{8}$ The Nigerian Minerals and Mining Act(2007) Section 116 [1].
} 


\section{LINKAGES BETWEEN DIFFERENT SECTORS SUPPORTING MINING ACTIVITIES}

The mining sector can improve its contribution to broad based development if it is integrated into the national and regional economic fabric through linkages. The Lagos Plan of Action for Economic Development of Africa 1980-2000 called for the establishment or strengthening of national machinery for the creation of policies to ensure that proper backward and forward linkages exist between these resource sector and sectors of the economy in order to promote integrated rural development, (ECA, 2011). Recent thinking has once again reawakened interest in linkage for economic development, including corridor development and clustering, to facilitate growth in depressed economic environments. This has been shaped by the experiences of resources-rich countries such as Canada, Finland, Norway, Sweden, the United States, to some extent, Australia, whose economies have evolved and have developed linkages between the mining industry and other sectors of the economy, (ECA, 2011).

Wise and Shtylla (2007:9) advance that the International Council of Mining and Metals (ICMM)'s Resource Endowment Initiatives research found that Chile has developed stronger linkages between the mining industry and other sectors of the local economy than other mining countries. Mining sites become centres of growth instead of enclaves and agglomeration not only increased productivity, but also raises income among the local population and economic growth of greater significance, (ECA, 2011). According to the ECA (2011:121) setting up a gold, chrome, iron ore or diamond mine typically give rise to backward/upstream linkages (to the mine) and forward/downstream linkages to beneficiates or processors of mine's output. The other linkage includes side-stream linkages to industries or organisations providing technological, human resources and infrastructure inputs and lateral migration linkages, (development of alternative uses of generic technologies used in the industry). Andres Mejia (2011:5) adds that there are also indirect linkages through investments, which in turn enable better social services and catalyze improvements in physical infrastructure

\section{RESEARCH METHODS}

The study utilised a descriptive survey research design in examining strategies of harnessing mineral resources for community empowerment, poverty reduction and infrastructure development in Gwanda rural district. Data was collected through questionnaires, document reviews, and key informant interviews.

\section{Population and Sampling}

The mines in Gwanda Rural District Council (GRDC), sector ministries, the wards and villages situated close to the mines constituted the population of the research. The research for this article targeted the mining companies, local communities close to the mining companies, the Ministry of Mines, Ministry of Youth Development, Indigenisation and Empowerment, Environmental Management Agency (EMA), GRDC and the District Administrator's office. The list of mines in Gwanda district, the list of wards and list of villages in these wards was used as a sampling frame for the research. The sample consisted of 50 respondents and they included 30 research participants from the local community, 10 key officials from the GRDC and the DA's office, 5 key informants from the mining 
companies and 5 key informants from the sector ministries. The names of villages, the mine managers, the District Administrator officers, sector ministries officials and the Rural District Council officials constituted the sampling units. Purposive sampling was used to select key informants and other key stakeholders who are actively involved with mining issues. This type of sampling was centred wholly on the judgement of the investigator, in that a sample was made up of elements that include the most characteristics, representative or typical attributes of the population (Neuman, 2006).

The study site was selected because it is one of the many mining districts of Zimbabwe and is endowed with minerals such as gold and cement. There are 21 wards in Gwanda district and some of these wards have operational mines. There are various mines which are located within the communal, resettlement and commercial areas. These mines are Vumbachikwe, Blanket mine and Colleen Bawn which are located within a radius of $30 \mathrm{kms}$ from the Gwanda District centre.

\section{RESULTS AND DISCUSSION}

The research specifically addressed the following two objectives:

a. To examine how local authorities harness mineral resources to enhance community empowerment, poverty reduction and infrastructure development

b. To examine the mining policies and legislative frameworks which can enhance the harnessing of mineral resources for community empowerment, poverty reduction and infrastructure development in Gwanda district in Matabeleland.

\section{Corporate Social Accountability and Responsibility Initiatives}

Political and economic analysts have underscored the need for policy frameworks that clearly state the roles and responsibilities of mining companies and government. Respondents' perception on the legal status of the corporate social accountability and responsibility initiatives is reflected in Table 1 below.

Table 1. Mandatory Corporate social accountability and responsibility initiatives.

\begin{tabular}{|c|c|c|c|c|c|}
\hline \multicolumn{2}{|c|}{ Response } & Frequency & Percent & Valid Percent & Cumulative Percent \\
\hline \multirow{3}{*}{ Valid } & Yes & 41 & 93.2 & 93.2 & 93.2 \\
\cline { 2 - 6 } & Don't know & 3 & 6.8 & 6.8 & 100.0 \\
\cline { 2 - 6 } & Total & 44 & 100.0 & 100.0 & \\
\hline
\end{tabular}

Ninety-three percent of the respondents agreed that the state must ensure that corporate social accountability and responsibility initiatives are mandatory mechanisms that directly benefit the affected communities. However, $7 \%$ of the respondents did not give a conclusive answer. Results imply that the majority of the respondents understood the concept of corporate social accountability and responsibility initiatives and hence felt that these initiatives must be mandatory in order to ensure the transfer of social and economic benefits 
to the community. These results are in harmony with the Zimbabwe Mining Indaba(2012)'s resolution that the Zimbabwe government must ensure that Corporate Social Accountability and Responsibility shifts from being a voluntary to mandatory mechanism with agreed minimum standards which directly benefit the local indigenous communities. Similar sentiments were expressed by the United Nations Economic Commission for Africa (2011) which warned that without policy frameworks compelling mining companies to transfer social and economic benefits to the community, community concerns continued to be treated as peripheral and any contributions were charity.

\section{Legislative framework for Corporate Social Responsibility in Zimbabwe}

In view of the discussion on corporate social and accountability initiatives above, the communities noted that there was a legislative framework for corporate social responsibility in Zimbabwe as shown in Figure 1 below.

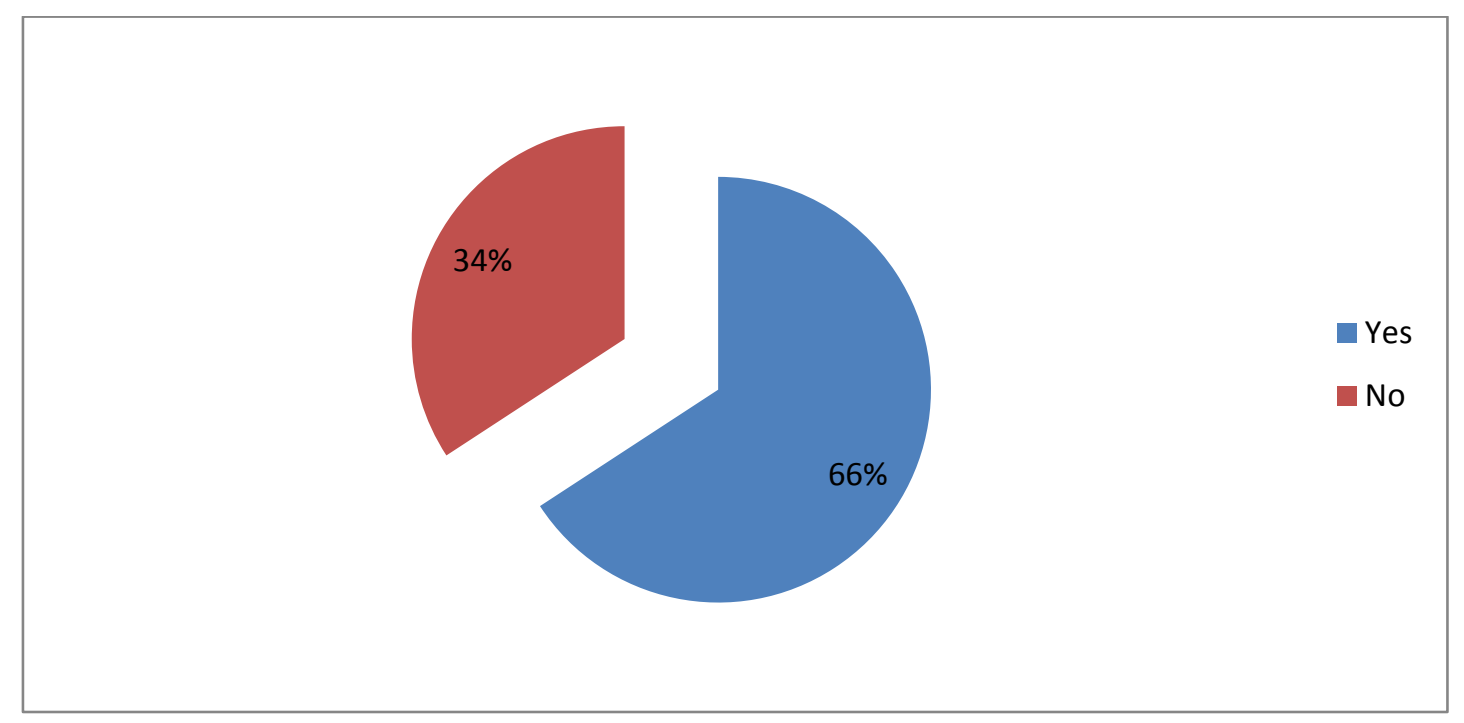

Figure 1. Presence of legislative framework for corporate social responsibility in Zimbabwe.

Sixty-six percent of the respondents indicated that there was a legislative framework for corporate social responsibility in Zimbabwe. Thirty-four percent of the respondents indicated that there was no legislative framework for the social corporate responsibility in Zimbabwe. On further probing the majority of the respondents identified the Amended Mines and Minerals Act, Indigenous and Economic Empowerment Act and a statutory instrument for Community Share Ownership Trust (CSOT).

These results are consistent with earlier findings by Murombo (2010) who stated that Zimbabwe has fast tracked economic empowerment through the indigenisation legislation. Musarurwa (2012) also advanced that the model of Zimbabwe's indigenisation and economic empowerment law places prominence on wealth creation through broad-based participation of indigenous people in economic activity. Hence the communities who participated in the research justified their view by giving specific examples of CSR projects implemented in Gwanda Rural District. They noted that mines have ploughed the profits back to the community through various projects. The identified projects include, construction of houses for their employees, construction of schools and clinics, construction of dams and dam 
canals, drilling of boreholes in irrigation schemes, construction and maintenance of roads, completion of incomplete classroom blocks and clinics, provision of employment opportunities and fencing of schools.

\section{Creation of Direct and Indirect Linkages with the rest of the economy}

The mining sector could improve its contribution to social and economic development if it was integrated into national and regional economic fabric through linkages. Respondents interviewed felt that mining sites must be centres of innovation and development which could be tapped by the local communities.

Table 2. Creation of Direct and Indirect Linkages with the rest of the economy.

\begin{tabular}{|c|c|c|c|}
\hline \multicolumn{2}{|c|}{ Responses } & Frequency & Valid Percent \\
\hline \multirow{4}{*}{ Valid } & Yes & 43 & 100.0 \\
& No & 0 & 0 \\
\cline { 2 - 4 } & Missing System & 1 & \\
\hline \multicolumn{2}{|c|}{ Total } & 44 & \\
\hline
\end{tabular}

Table 2 indicates that about $98 \%$ of the respondents agreed that mining activities must create direct and indirect linkages with the rest of the economy if their benefits have to be felt by all citizens. Surprisingly no one opposed the view. However $2 \%$ represent one respondent who did not provide an answer to the question asked. Technically all the respondents supported the view that creation of direct and indirect linkages with the rest of the economy could result in maximum benefits to a majority. Weber-Fahr, Strongman, Kunanayagam, and Sheldon (2001) found that mining has the potential of developing downstream and lateral economic activity with suppliers and refiners, particularly for small and medium-sized enterprises, in turn generate employment opportunities for non-miners in the surrounding areas.

On responding to the question on how linkages in mining could contribute to social and economic empowerment of local communities, respondents gave different ways. These included food supply to the mine, manufacture of mining inputs, provision of security services and supplying labour.

\section{Implementation of Community Development Programmes}

Respondents noted that it was unacceptable for indigenous rural people to live without basic services such as water, health care, electricity and sanitation, yet their mineral resources are being extracted by mining companies. Table 3 below shows the views of respondents on the need to support community development programmes by mining companies.

Almost $100 \%$ percent of the respondents indicated that the mining industry must accept the need to implement development programmes focused on water and sanitation, health care, electricity, road construction and other social infrastructure. 
Table 3. Implementation of Community Development Programmes.

\begin{tabular}{|c|c|c|c|}
\hline \multicolumn{2}{|c|}{ Responses } & Frequency & Valid Percent \\
\hline \multirow{4}{*}{ Valid } & Yes & 43 & 100.0 \\
& No & 0 & 0 \\
\cline { 2 - 4 } & Missing System & 1 & \\
\hline \multicolumn{2}{|c|}{ Total } & 44 & \\
\hline
\end{tabular}

Results suggest that communities supported the view that the mining industry should implement development programmes focused on water and sanitation, health care, electricity, road construction and other social infrastructure. These results are consistent with earlier findings by Musvoto (2001:9) who advanced that "mining sector had managed to assist communities in areas such as health, education, infrastructure development and setting up of small enterprises in various sectors, which benefit local people". Hence the mining sector has always had a positive impact on many lives through the provision of infrastructure and essential services in remote areas where none existed.

\section{Frameworks compelling Mining Companies to employ locals and the improve social welfare of the communities}

Local communities have noted that the mining companies should generate employment opportunities for local communities who are the indigenous residents of the areas where the mine is located. Improving the social welfare of the community was also viewed as another area requiring attention from the mining companies.

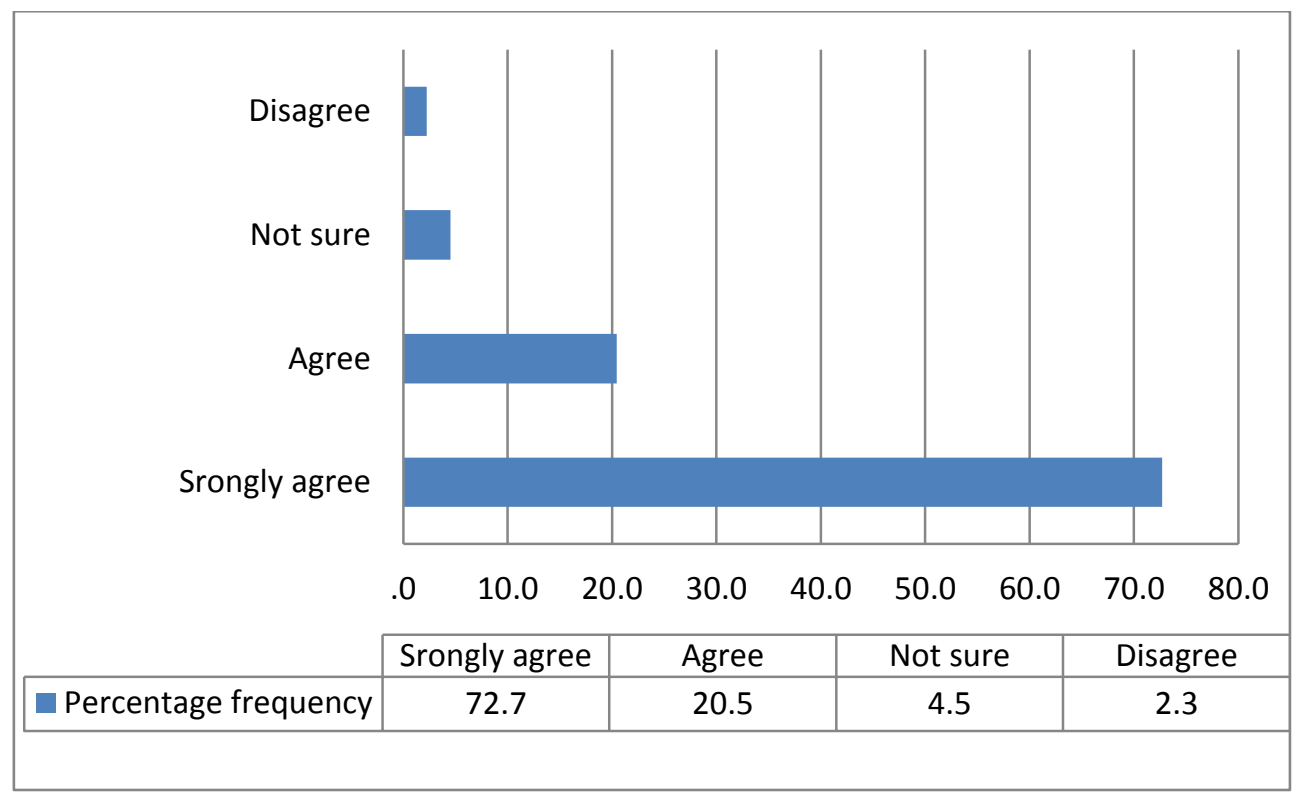

Figure 2. Frameworks compelling mining companies to employ locals and improve social welfare of the community. 
Figure 2 above reveals that $73 \%$ of the respondents supported the view that there must be a framework compelling mining companies to contribute to the employment of locals and improving the social welfare of communities affected by mining activities. Just over $2 \%$ of the respondents opposed the view. These results suggest that communities are of the view that government must enact policy frameworks which compel mining companies to employ locals and improve the welfare of communities.

It would appear these results are consistent with earlier findings by Bryan and Hofmann (2007:24) who revealed that civic activists in Ghana advocate for government policies that ensure jobs are created and that benefits or other forms of compensation accrue to communities where natural resources are extracted.

\section{Effective harnessing of Mineral Resources for economic and social empowerment.}

Prudent, efficient, equitable and sustainable exploitation and management of mineral resources can make significant contributions to social and economic empowerment. Communities which participated in the study cited different strategies which can be implemented by government to effectively harness mineral resources, as shown in Figure 3 below.

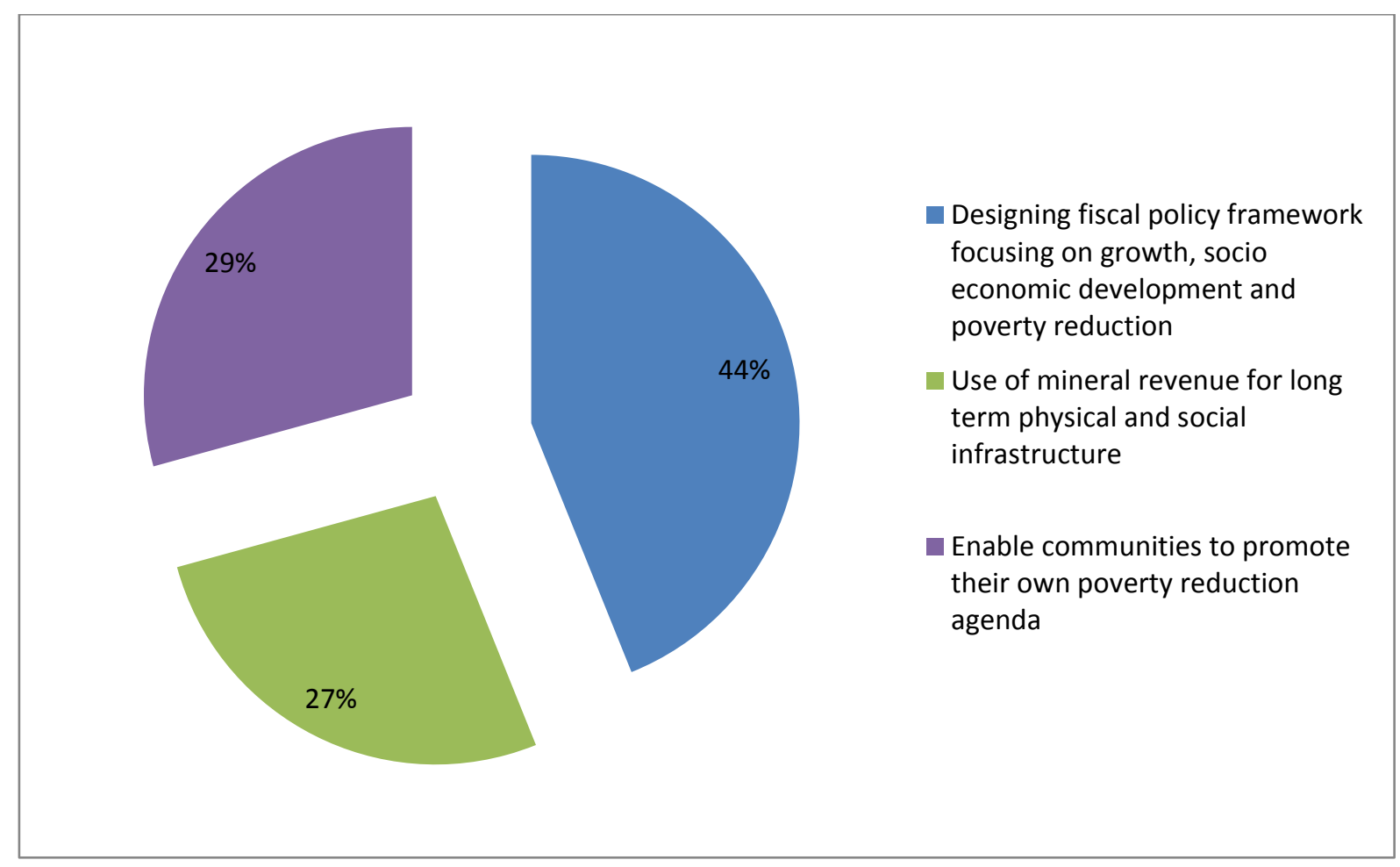

Figure 3. Effective harnessing of mineral resources for economic and social empowerment.

A total of $44 \%$ of the respondents advanced that government can ensure the effective harnessing of mineral resources for economic and social empowerment through designing fiscal policy frameworks focusing on growth, socio-economic development and poverty reduction, $27 \%$ of the respondents identified the use of mineral revenue for long term physical and social infrastructure development as one of the strategy of effective harnessing 
of mineral resources for economic and social empowerment and $29 \%$ were of the opinion that harnessing of mineral resources should enable communities to promote their own poverty reduction agenda.

Results in Figure 3 suggest that communities viewed designing of fiscal policy frameworks focusing on growth, socio-economic development and poverty reduction as one of the strategies for effective harnessing of mineral resources for economic and social empowerment. Utilisation of mineral revenue for long term physical and social infrastructure development was also noted as another strategy to effectively harness mineral resources for economic and social empowerment. Frucs and Agba (2007) contend that government can promote effective harnessing of mineral resources for social and economic empowerment through implementing a policy framework to ensure mineral wealth is captured and creates long lasting benefit for local community. The model of Zimbabwe's indigenisation and economic empowerment law places prominence on wealth creation through broad-based participation of indigenous people in economic activity, (Musarurwa, 2012).

\section{Contribution of Large-scale Mining to Community Livelihoods}

It should be acknowledged that the mining sector in Zimbabwe has always had a positive impact on many lives. Many local communities in Zimbabwe believe that they should also share in the wealth created by mines. Hence large scale mining companies have implemented different projects as part of the corporate social responsibility. Figure 4 below shows the views of community on the contribution of large -scale mining to community projects.

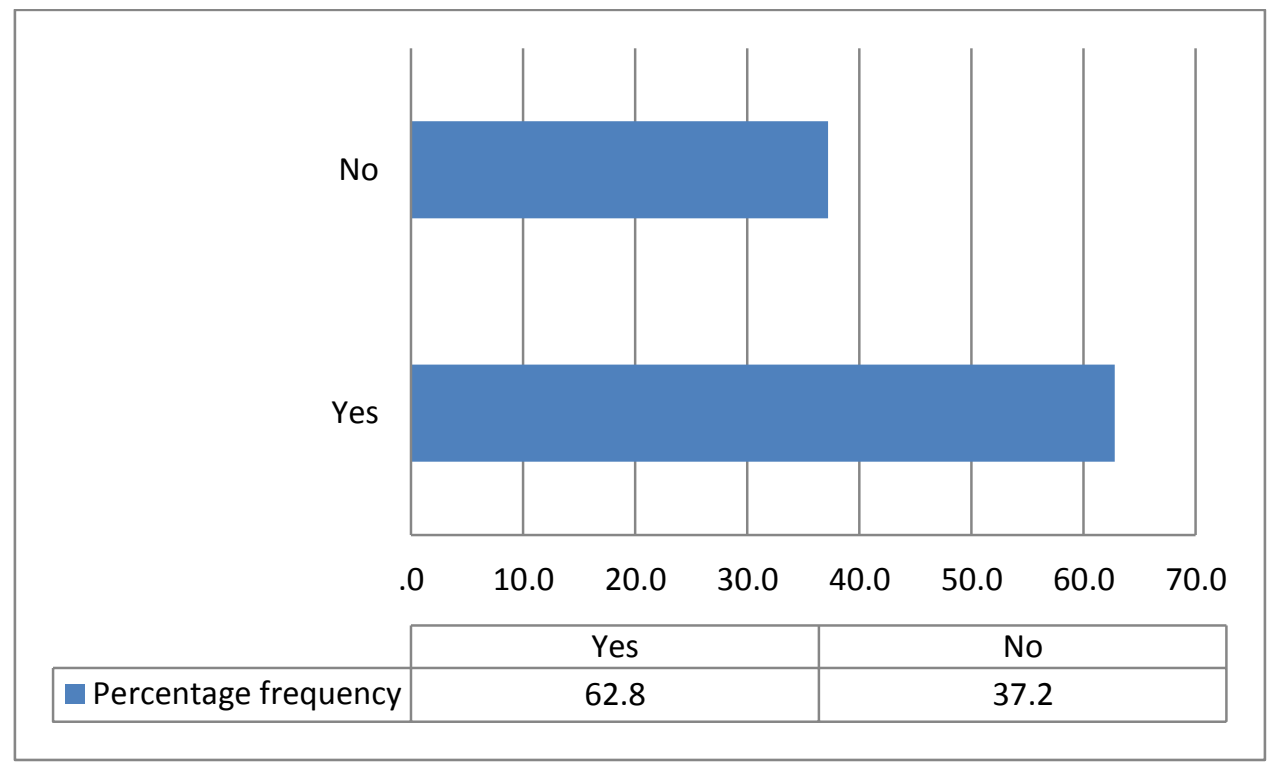

Figure 4. Contribution of Large-scale Mining to Community Livelihoods.

At least $63 \%$ of the respondents supported the view that large scale mining has contributed to higher incomes, to better nutrition; private financing of primary health care, and better education and better standard of living for the community, compared to $37 \%$ of the respondents who opposed the view. 
These results suggests that communities acknowledge that large-scale mining can contribute to higher incomes, better nutrition, private financing of primary health care, better education and better standard of living for the community.

These results are in agreement with earlier findings by Mate (2002) who stated that most of larger mines had established foundations through which they were involved in the provision of health and education infrastructure as well as provision of non-mine training education.

In Tanzania, DeBeers has partnered with government, communities and development organisations to produce viable and potential transferable model of improving qualities of life in mining based rural populations, by enhancing artisanal and small-scale business model and exploring alternative projects,(Wise and Shtylla, 2007)

\section{CONCLUSIONS}

The harnessing of mineral resources in any country has been a contested terrain. Governments have been engaged in a war of words with private companies on the need to share the proceeds from these minerals through corporate social responsibility, for instance, engaging in activities such as dam construction, road rehabilitation schools construction and many others to improve the livelihood of communities within their catchment areas. Of late in Zimbabwe, the government has embarked on a massive indigenization drive that has seen large scale mines compelled by law to seed at least $10 \%$ of their mineral revenue to CSOTS. This has been met with some resistance by some large mining concerns, however a number of mines have complied with the directive.

In Gwanda district mines like Vumbachikwe have complied and have even disbursed funds to these trusts for community projects, (Mabhena and Moyo, 2014). One of the major concerns of this article is that when the state is talking community empowerment it negates the need to economically empower individuals let alone households, rather it views corporate social responsibility by companies and the implementation of community projects funded through CSOTS as empowerment.

We argue that for community empowerment to bring about poverty reduction and infrastructural development in Gwanda district it should also focus on individual and household empowerment as a prelude to community empowerment. Pro poor policies should be crafted and beneficiaries made aware of these. Furthermore we argue that the CSR is not a new phenomenon in Zimbabwe's large scale mining, thus refuting the notion that large scale mines have not been taking an active role in community development in their catchment areas.

However we ascertain that there is a need for the harmonization of legislation that govern the operations of other state agencies and non state agencies with the indigenization act in contributing to community empowerment for sustainable livelihoods.

The article therefore concludes that pro poor mining policies that ensure the harnessing of mineral resources for community empowerment, poverty reduction and infrastructure development are paramount for livelihoods of communities in the mining catchment areas. Artisanal mining needs to be regularised and the majority who might not see the benefit of community share ownership schemes in the short term be given a chance and supported through policies that will enable them to engage in friendly mining operations that would not erode and contaminate the environment for future generations. 


\section{Acknowledgements}

This article was written by Mr Funa Moyo and Dr Clifford Mabhena who are Lecturers at the Institute of Development Studies-National University of Science and Technology (NUST). We thank Gwanda Rural District Council and Sector Ministries whose officials contributed immensely to the research of this article. An appreciation also goes to Mr Mandla Maphosa, lecturer at the Institute of Development Studies-National University of Science and Technology (NUST) for his critical inputs.

\section{References}

[1] Andres Mejia, A. 2011. The Impact and Effectiveness of Accountability and Transparency Initiatives: The Governance of Natural Resources. London: Institute of Development Studies, University of Sussex.

[2] Anglo American Case Study, 2011. Anglo American Promoting Sustainable Entrepreneurship. Johannesburg: Business Call for Action.

[3] Brands, H.W. 2002: The age of gold. The California gold rush and the New American dream. New York and London, Doubleday.

[4] Bryceson D.F., MacKinnon D., Journal of Contemporary Studies 30(4) (2012) 523-537.

[5] Bryceson D.F., Mwaipopo, 2010. Rural-Urban Transition in Tanzania's North-west mining frontier, 2010. In rural-urban dynamics: African and Asian frontiers, ed. J, Agergaard, N, Fold and K.V Gough 158-74, London, Routledge.

[6] Bryan, S and Hofmann, B.2007. Transparency and Accountability in Africa's Extractive Industries: The Role of the Legislature. Washington DC: National Democratic Institute for International Affairs.

[7] Economic Commission for Africa, 2011. Minerals and Africa's Development. The International Study Group Report on Africa's Mineral Regimes. Addis Ababa: United Nations Economic Commission for Africa.

[8] De Boeck F., Development and Change 29 (1998) 777-810.

[9] Dore E., Environment and History 6 (2000) 1-29

[10] Holliday, J.S. 2002. The world rushed in: The California gold rush experience. Norman OK: University of Oklahama Press.

[11] Frucs, J.M.E. and Agba, A.V. 2007. An Economic Analysis of National Resources Sustainability for the Mining Sector Component- Nigeria. Lagos: Wardell Armstrong International.

[12] Godfrey B.J., Geographical Review 82(4) (1992) 458-69.

[13] Government of Zimbabwe, 2007. The Indigenization and Economic Empowerment (General) Regulations SI 21 of 2010 (IEE Regulations . Section 23 of the Indigenisation and Economic Empowerment Act 14 b of 2007. Harare: Government of Zimbabwe.

[14] Impala Bafokeng Trust (IBT) Annual Report, 2011. Helping to Build Sustainable Communities. Mafikeng: Impala Bafokeng Trust. 
[15] Kanyenze, G, Kondo, T, Chitambara, P and Martens, J. 2011. Beyond The Enclave. Towards a Pro- Poor and Inclusive Development Strategy for Zimbabwe. Harare: Labour and Economic Research Institute of Zimbabwe and Alternatives to NeoLiberalism in Southern Africa.

[16] Lawrie M., M. Tonts, P. Plummer, Australian Geographer 4(2) (2011) 139-164.

[17] Mabhena C., Journal of Contemporary African Studies 30(2) (2012) 219-233.

[18] Mabhena, C. and Moyo, F. 2014. Community Share Ownership Scheme and Empowerment. The case of Gwanda Rural District, Matabeleland South Province in Zimbabwe. IOSR. JHSS, vol 19 issue, 1 ver.xi (Feb. 2014), pp. 72-85.

[19] Maodza, T. (Senior Reporter) 2012.Community Share Ownership Trusts. 29 June 2012. Harare: The Herald.

[20] Martin, A. and Taylor, B. 2012. Reap What You Show: Greed and Corruption in Zimbabwe's Marange Diamond Fields. Canada: Partnership Africa Canada.

[21] Mate, K. 2002. Communities, Civil Society Organisations and the Management of Mineral Wealth. London: International Institute for Environment and Development (IIED) No 16.

[22] Matyzak, D.2012.Digging up the Truth: The legal and Political Realities of Zimplats Saga. Harare: Research and Advocacy Unit.

[23] Mineral and Petroleum Resources Development Act 2002.Pretoria: Government of South Africa.

[24] Murombo, T. 2010. Law and the indigenisation of mineral resources in Zimbabwe: Any equity for local communities. Johannesburg: University of Witwatersrand.

[25] Musarurwa, T. (Business Reporter), 2012. Indigenisation Boom for Workers. Harare: The Herald, the Herald Business News, 01 May, 2012.

[26] Neuman, W.L. 2006. Social Research Methods. Qualitative and Quantitative Approaches. New York: Allyn and Bacon.

[27] O' Connell, A.S. and Lindsay, D. 2011. Development and AID in Sub-Saharan Africa. (Revised Edition). Rome: Swarthmore College.

[28] Pedro, A.M.A.2005. Mainstreaming Mineral Wealth in Growth and Poverty Reduction Strategies. ECA Policy Paper No 1. Addis Ababa: Economic Commission for Africa.

[29] Rakodi C., Third World Planning Review 8(3) (1986) 193-217.

[30] Richards, P. 1996. Fighting for the rain forest: War, Youth and Resources in Sierra Leone. London, James Currey.

[31] Storey K., Australian Geographer 32(2) (2001) 138-148.

[32] Saunders R. 2007. Mining and Crisis in Zimbabwe. Cape Town: Fatal Transactions Campaign and Netherlands Institute for Southern Africa.

[33] Swanson M., Journal of African History 18(3) (1977) 387-410.

[34] The African National Congress (ANC) Policy Discussion, 2012. State Intervention in the Mineral Sector (SIMS). Maximising the Developmental Impact of the People's Mineral Assets. Johannesburg. The African National Congress. 
[35] Tonts M., M. Taylor, Urban Studies 47 (2010) 2641-2664.

[36] United Nations Economic and Social Council. Economic Commission for Africa, 2009. Africa Review Report on Mining. Sixth Session. Addis Ababa: Committee on Food Security and Sustainable Development.

[37] Weber-Fair, M., Strongman, J., Kunanayagom, R., Mc Mahan, G and Sheldon, C. 2001. Mining and Poverty Reduction.

[38] Wise, H. and Shtylla, S. 2007. The Role of the Extractive Sector in Expanding Economic Opportunity. New York: Harvard University and John F. Kennedy School of Government.

[39] Zimbabwe Mining Indaba, 2012. The Zimbabwe Alternative Mining Indaba Declaration, $11^{\text {th }}-13^{\text {th }}$ September 2012. Harare: Zimbabwe Environmental Law Association, Chiadzwa Community Development Trust (CCDT). 